\title{
Visszatekintés egy korai korpuszelemzésre
}

\author{
Klaudy Kinga
}

\author{
klaudy.kinga@btk.elte.hu \\ Eötvös Loránd Tudományegyetem Bölcsészettudományi Kar \\ Fordító- és Tolmácsképző Tanszék
}

\begin{abstract}
Kivonat: A szerző 1980-ban végzett elemzést összehasonlítható (comparable) korpuszokon. Az elemzést manuálisan végezte, de az eredmények ma is vállalhatók. Oroszból fordított magyar szakmai és tudományos szövegeket hasonlított össze hasonló időben keletkezett és hasonló témájú autentikus magyar szövegekkel. Vizsgált bizonyos grammatikai mutatókat (a mondatok és a mondategységek hosszúsága, szerkesztettsége, mélysége, bővítettsége), valamint bizonyos aktuális tagolási típusokat (visszautaló téma, informatív téma, retorikus téma, emelkedő réma, ereszkedő réma, egyenletes réma stb.). A vizsgálat kimutatta, hogy a fenti grammatikai mutatók és aktuális tagolási típusok gyakorisága tekintetében eltérések vannak a fordított magyar szövegek és az eredetileg is magyarul fogalmazott szövegek között. A grammatikai tagolásban és az aktuális tagolásban kimutatott eltérő disztribúciós jegyek alapján a fordított szövegeket kvázi-helyes magyar szövegnek nevezte.
\end{abstract}

Kulcsszavak: fordított és eredeti magyar szöveg, grammatikai tagolás, aktuális tagolás, disztribúció, kvázi-helyesség

\section{Bevezetés}

Egy olyan kutatásra szeretnék visszatekinteni, amelyet 1980-ban nyújtottam be kandidátusi értekezésként, 1981-ben védtem meg, és 1987-ben jelent meg az Akadémiai Kiadónál Forditás és aktuális tagolás címmel. Papp Ferencnek, a számítógépes nyelvészet magyarországi megteremtőjének tanítványaként természetes volt, hogy a fordításkutatásban is

Klaudy Kinga: Visszatekintés egy korai korpuszelemzésre. In: Robin E., Seidl-Péch O. (szerk.) 2020. Fókuszban a forditott és a tolmácsolt szöveg: korpuszalapú fordításkutatás Magyarországon. Segédkönyvek a nyelvi közvetítésről I. Budapest: ELTE BTK Fordítástudományi Doktori Program, MANYE Fordítástudományi Szakosztály. DOI: https://doi.org/10.36252/Nyelvikozvsegedkonyv1.2 
vonzottak az egzakt módszerek, és bár azok a szövegcsoportok, amelyeket vizsgáltam, nem voltak gépileg olvashatók és automatikusan lekérdezhetők, mégis korpusznak neveztem öket, mint ahogyan minden nyelvész annak nevezte akkoriban a nyelvi adatok forrásaként használt szövegeit. Részben azért érzem most (40 évvel később) érdemesnek feleleveníteni ezt a kutatást, mert több szempontból elörevetítette a Mona Baker által 1993-ban megindított korpuszalapú fordításkutatás elveit, részben pedig azért, mert néhány megállapítását a későbbi nagyméretü korpuszokon végzett elemzések is igazolták, vagy még igazolhatják.

Megjegyzem, hogy a visszatekintés müfajából fakadóan nem fogom sem a használt terminusokat, sem a felhasznált szakirodalmát részletezni, mindez megtalálható és olvasható az eredeti müben. Ez különösen az aktuális tagolással foglalkozó fejezetben lesz szembetűnő, ahol a téma, réma, tematikus szakasz, rematikus szakasz, rematikus csúcs, kommunikatív dinamizmus fogalmát úgy fogom használni, mint amelyek a nyelvtudományban közismertek és nem szorulnak magyarázatra. Ugyanebből az okból minimális mennyiségü lesz a nyelvi példák száma is, továbbá csak az oroszból fordított magyar (OM) és az autentikus magyar (M) szövegcsoportból hozok példákat.

\section{A kvázi-helyesség fogalma és a korpusz összeállításának elvei}

A kutatási témát oktatói munkám tapasztalatai hozták. Az 1973-as tanévtől az ELTE BTK Fordító- és Tolmácsképző Csoportjában folyó posztgraduális fordítóképzésben oktattam orosz-magyar fordítástechnikát, és arra próbáltam nyelvészeti magyarázatot találni, miért olyan nehezen érthetőek az oroszul amúgy jól tudó, orosz szakot végzett hallgatók magyarra fordított szövegei, amikor mondataik egyenként grammatikailag helyes magyar megfogalmazásnak tekinthetők. Véletlenül bukkantam rá Papp Ferenc 1972-ben megjelent cikkére, aki ugyanezt a jelenséget a magyar anyanyelvủ orosz szakos egyetemi hallgatók orosz nyelvü fogalmazásaiban mutatta ki, és kvázi-helyességnek nevezte. Idézem az ő meghatározását orosz nyelvü cikkének 2005-ben megjelent magyar fordításából: 
a) a szöveg minden mondata az adott nyelv grammatikai szabályai szerint épül fel (az anyanyelvi beszélők minden mondatot nyelvtanilag helyes mondatként fogadnak el);

b) a szövegben közvetlenül egymás mellett álló minden egyes mondatpár a topic-comment szabályai szerint épül fel, a megfelelő nyelvi eszközök kötik őket össze (az anyanyelvi beszélők minden szomszédos mondatpárt helyesen szerkesztett és egymáshoz helyesen kapcsolt mondatként fogadnak el);

c) az egész szöveget az anyanyelvi beszélők elutasítják, mint olyan szöveget, amely nem felel meg az adott nyelven helyesen szerkesztett szövegekről alkotott intuitív elképzeléseiknek. (Papp 2005: 122, Répási Györgyné fordítása)

A kvázi-helyesség első okaként Papp a következőt említette: „Az idegen nyelvet magas szinten elsajátító személy hibát követhet el bizonyos szövegjelenségek használatának statisztikai eloszlásában" (Papp 2005:123). Példának azt a jelenséget hozta fel, hogy az oroszul fogalmazó magyarok általában kevesebb szenvedő szerkezetet, igeneves szerkezetet és több mellékmondatot használnak, mint ahogyan az az autentikus orosz szövegekben szokás.

Nekem nagyon fontosak voltak ezek a gondolatok, mert megerösítettek abban, hogy a magyarra fordított szövegek idegenszerüségét is csak szövegszinten lehet megragadni. Méghozzá úgy, és ez már a saját leleményem volt, hogy autentikus magyar szövegekkel vetjük őket egybe. Ez volt az első „korát megelőző” ötletem, hiszen nem tudok róla, hogy akkoriban bárki végzett volna egybevetést a fordítás eredményképpen keletkezett célnyelvi szövegek és az eredetileg is célnyelven írt szövegek között. Mona Baker 1995-ös programadó cikkében írja le a fordításkutatásban használható szövegkorpuszok fajtáit: (1) párhuzamos korpusz, (2) multilingvális korpusz, (3) összehasonlítható korpusz. A nyolcvanas években az utóbbi terminust ugyan még nem ismerhettem, de a Baker definíciójának megfelelö összehasonlítható (comparable) korpuszt építettem, amikor az 
oroszból fordított magyar szakmai és tudományos szövegcsoport mellett azonos múfajú, azonos időben keletkezett autentikus magyar szakmai és tudományos szövegcsoportot hoztam létre.

A másik ilyen „elörevetített” gondolatom a fordított szövegek értékítélettől mentes leírásának gondolata volt. Ezt akkor így fogalmaztam meg:

(...) nekünk nem az a célunk, hogy a ,germanizmusok” ellen harcolók nyomdokain haladva most „russzicizmusokra” vadásszunk a fordított szövegekben, netán „ki akarjuk irtani öket”, hanem az, hogy a fordított szövegeket nyelvi ténynek fogva fel megpróbáljuk különböző szempontokból megvizsgálni és leírni őket. (Klaudy 1987:7)

A két magyar szövegcsoport szövegszintü különbségeinek kimutatásán kívül az orosz szöveg interferenciájára is kíváncsi voltam, ezért korpuszom egy orosz nyelvű szövegcsoportot is tartalmazott. Mivel manuálisan elemeztem, úgy gondoltam, hogy 200200 mondatot elemzek mindhárom szövegcsoportból. Hogy minél változatosabb legyen a merítés, háromszor 20 könyvből választottam ki egyenként 10 mondatot a könyvek különböző részeiből véletlenszerủ mintaválasztással (ahol táblázat vagy ábra volt, ott módosítottam). Volt tehát három szövegcsoportom: autentikus orosz szakmai és tudományos szövegek $(\mathrm{O})$, oroszból fordított magyar szakmai és tudományos szövegek $(\mathrm{OM})$, és autentikus magyar szakmai és tudományos szövegek (M).

Két megjegyzés a fordított szövegekröl: (1) az OM szövegcsoportot függetlenül állítottam össze, tehát nem az O szövegcsoport fordításait tartalmazta; (2) az OM szövegcsoportban nem használtam hallgatói fordításokat, minden fordítás nyomtatásban megjelent szöveg volt (adataikat ld. Klaudy 1987: 122-124). A korpusz szövegeinek kiválasztása is arra utal, hogy nem hibás szövegekre vadásztam, hanem az oroszból magyarra fordított szövegek általános jellegzetességeit akartam megragadni. 
Természetesen lehet vitatkozni arról, hogy a kvázi-helyesség terminus mennyire mentes az értékítélettől, de akkor úgy döntöttem, hogy a dolgozat céljának megfelel. Későbbi munkáimban már nem használtam, mert akkor már inkább a fordítás folyamata, azaz az átváltási müveletek rendszerének leírása foglalkoztatott, és nem a fordított szövegek jellegzetességeinek leírása.

A célnyelvi elemek eltérő disztribúcióját egyébként Mona Baker 1993-as cikkében felveszi a feltételezett és a jövőben korpusznyelvészeti eszközökkel vizsgálandó fordítási univerzálék közé, amelyek nyelvpártól és fordítási iránytól függetlenül jellemzik a fordított szövegeket (Baker 1993: 245). Baker az univerzálék felsorolásakor abból indul ki, hogy a fordítások szövege nem jobb, nem rosszabb, csak más, és ennek a másságnak a megnyilvánulásait tekinti univerzálénak (Baker 1993: 234). A másság megállapításával azonban nem zárhatjuk ki azt a tényt, hogy az olvasók számára az eltérő disztribúció megértési problémákhoz vezethet, és ezzel veszélyeztetheti a kommunikatív ekvivalenciát.

\section{Kvázi-helyeség az OM mondatok grammatikai tagolásában}

Az oroszból magyarra fordított szövegek kvázi-helyességét két szempontból vizsgáltam meg: a három szövegcsoport mondatainak grammatikai tagolásában és aktuális tagolásában. A grammatikai tagolás tekintetében az volt a hipotézisem, hogy a fordított magyar szövegek és az autentikus magyar szövegek közötti szintaktikai különbségeket számszerüen is ki lehet mutatni, és bizonyos szintaktikai mutatók tekintetében az oroszból fordított (OM) magyar szövegek valahol félúton lesznek az orosz szövegek (O) és az autentikus magyar (M) szövegek között.

A kutatás módszere a három szövegcsoport 600 mondategészének mondategységekre való bontása volt. A mondategész és a mondategység terminust Deme Lászlótól (1971) kölcsönöztem, mert el akartam kerülni a fömondat és a mellékmondat terminus használatát. A mondategész terminus magától értetődő, a mondategység pedig egy predikatív egységet jelent. Ezután az így kapott 1342 mondategység szintaktikai képletének leírása következett oly módon, hogy az alany (A), az állítmány (Áll), a tárgy (T), a határo- 
zó (H) és a kötőszó (k) mondatszintü elemnek számított, a jelzői bővítmények pedig mondatszint alatti elemként (mélységüktől függetlenül) alsó indexbe kerültek, az alapszótól jobbra vagy balra. A mondatok képletének leírását és az adatok felvételének módját egy OM szövegcsoportból származó mondat képletének leírásával szemléltetem:

(1) Mindezek a különböző időkbe tartozó és a tudományos folyamat szerves részét alkotó elemek bonyolult, dialektikus kölcsönhatásban vannak egymással, és ebböl fakad a tudomány, mint bonyolult rendszer történetiségének törvényszerü jellege. (OM 1.2)

A mondat képlete: ${ }_{00} \mathrm{~A}-{ }_{2} \mathrm{H}-\mathrm{A} l 1-\mathrm{H} / \mathrm{k}-\mathrm{H}-\mathrm{A} l 1-{ }_{6} \mathrm{~A}$

\section{1. táblázat}

A három szövegcsoport összevetésének adatai

\begin{tabular}{|l|r|r|r|}
\hline Az összevetés egységei & O & OM & M \\
\hline mondatok száma & 200 & 200 & 200 \\
mondategységek száma & 354 & 453 & 535 \\
összes szövegszó & 3724 & 3755 & 3954 \\
mondatszintű elemek száma & 1462 & 1833 & 2277 \\
mondatszint alatti elemek száma & 2262 & 1922 & 1677 \\
balra álló mondatszint alatti elemek száma & 531 & 1830 & 1644 \\
jobbra álló mondatszint alatti elemek száma & 1731 & 92 & 33 \\
\hline
\end{tabular}

Látjuk, hogy az OM szövegcsoport első szövegének második mondatában a szövegszavak száma 26, az önálló mondategységek száma 2, a mondatszintü elemek száma 8 , a balra álló mondatszint alatti elemek száma 18. Az ilyen módon manuálás számlálás alapján kapott összesített adatokat az 1. táblázat tartalmazza. 
Az arányokat a 2., 3., 4. és 5. táblázat fogja szemléltetni. A 2. táblázatból láthatjuk, hogy az egy mondatra jutó szószám tekintetében nincs nagy különbség a három szövegcsoport között, de a mondategészek tagoltsága eltér: a legkevésbé tagoltak, azaz a legkevesebb mondategységet az orosz mondatok tartalmazzák (1,77 mondategység jut egy mondategészre), a legtagoltabbak az autentikus magyar szövegek mondatai $(2,67)$, a fordított mondatok tagoltsága pedig a kettő között van $(2,26)$.

\section{2. táblázat}

A mondategészek átlagos hosszúsága és tagoltsága

\begin{tabular}{|l|c|c|c|}
\hline Mondategészek/mondategységek & O & OM & M \\
\hline szó/mondategész & 18,62 & 18,77 & 19,77 \\
mondategység/mondategész & 1,77 & 2,26 & 2,67 \\
\hline
\end{tabular}

A mondategészek tagoltsága, azaz hogy a mondategészek hány önálló mondategységet tartalmaznak, tipikusan olyan sajátosság, amely szabad szemmel nem látható, nem vehető észre. A 2. táblázat mutatja, hogy a fordított szövegekben nő a mondategységek száma, tehát a fordítók próbálnak igésíteni, új predikatív egységeket alkotni, de a tagoltság nem éri el az autentikus magyar szövegekét.

Ezzel függ össze az, amit a 3. táblázat mutat, hogy az összes szövegszónak csak $39,25 \%$ van mondatszinten az orosz szövegekben, míg az autentikus magyar szövegekben 57,58\%-a. A fordított magyar szövegek újra a kettő között helyezkednek el (51,18\%).

\section{3. táblázat}

Az összes szövegszó megoszlása

\begin{tabular}{|l|c|c|c|}
\hline Összes szövegszó & O & OM & M \\
\hline mondatszinten állók & $39,25 \%$ & $48,81 \%$ & $57,58 \%$ \\
mondatszint alatt állók & $60,74 \%$ & $51,18 \%$ & $42,41 \%$ \\
\hline
\end{tabular}

Az olvasó számára a mondatszintű elemek azonnal felfoghatók, míg a mondatszint alatt elhelyezkedő, jelzői szerkezetekbe zsúfolt elemek nehezebben értelmezhetők. A fordítók 
igyekeznek ugyan felemelni a mondatszint alatti bővítményeket a mondat szintjére, de nem érik el az autentikus magyar szövegek szintjét.

A következö, 4. táblázat a mondatszint alatti bővítmények elhelyezkedését mutatja. Látjuk, hogy az orosz mondatszint alatti bővítmények az alapszótól balra is, jobbra is állhatnak. Az alapszótól balra helyezkedik el 23,47\%, jobbra pedig 76,52\%. Az autentikus magyar szövegekben viszont az alapszótól balra áll a bővítmények 98,3\%-a, a jobbra bővítés lehetősége megvan ugyan (pl. ugrás a sötétbe, harc a végsőkig stb.), de a magyar nyelvhasználat csak korlátozottan él vele. Az alapszótól jobbra álló határozói jelzőket leginkább csak címekben vagy mondatok végén találunk.

\section{4. táblázat}

A mondatszint alatti bövitmények elhelyezkedése

\begin{tabular}{|l|c|c|c|}
\hline $\begin{array}{l}\text { A mondatszint alatti bővítmények } \\
\text { elhelyezkedése }\end{array}$ & O & OM & M \\
\hline az alapszótól balra áll & $23,47 \%$ & $95,21 \%$ & $98,03 \%$ \\
az alapszótól jobbra áll & $76,52 \%$ & $4,78 \%$ & $1,96 \%$ \\
\hline
\end{tabular}

Köztudott volt eddig is, hogy az orosz főnévi csoportra a jobbra bővítés, a magyar főnévi csoportra a balra bővítés jellemző, elgondolkodtató azonban, hogy míg az oroszban az uralkodó jobbra bővítés csak 76,52\%-os, a balra bővítésre is jut 23,47\%. A mennyiségi és minőségi jelzők az alapszó előtt állnak, és csak a birtokos jelző és a határozói jelző kerül az alapszó mögé. Tehát az oroszban két lehetőség van a mondatszint alatti bővítmények elhelyezésére. A magyarban viszont az uralkodó balra bővítés 98,03\%-os, tehát differenciálatlanul minden mondatszint alatti bővítmény az alapszó elé kerül.

A fordításban az orosz főnévi csoportok jobbra álló határozói jelzői is a magyar alapszó elé, azaz balra kerülnek. Ahhoz, hogy a főnév elé kerülhessek, a fordítóknak jelzősíteni kell őket, amit általában üres, deszemantizálódott melléknévi igenevekkel oldanak meg (alapuló, célzó, fakadó, járó, történö, gyakorló, folyó). Ez volt egyébként az egyetlen adat, amelyet gépileg kaptam. Hell György készített nekem szógyakorisági statisztikát a 
BME Számítóközpontjában egy 10 ezer szavas OM és egy 10 ezer szavas M szövegröl, és a fordított szövegben 16 találatot kaptunk a folyó szóra, míg az autentikus magyarban egyet sem (Klaudy 1987: 21). A téma jellegéből adódóan vízi útról nem lehetett szó.

A bővítési lehetőségek közötti különbségek tükröződnek az 5. táblázatban, ahol a mondategységekkel kapcsolatos arányokat láthatjuk. A három szövegcsoport mondategységei majdnem azonos mennyiségü mondatszintü elemet tartalmaznak, de a mondatszint alatti elemek száma jelentősen eltér. Az orosz szövegcsoportban a mondategységek hoszszabbak, és több mondatszint alatti elemet tartalmaznak.

\section{5. táblázat}

A mondategységek átlagos hossza és bövitettsége

\begin{tabular}{|l|c|c|c|}
\hline Az összevetésben szereplő mutatók & O & OM & M \\
\hline szó/mondategység & 10,50 & 8,28 & 7,39 \\
\hline mondatszintű elem/ mondategység & 4,12 & 4,04 & 4,25 \\
\hline mondatszint alatti elem/ mondategység & 6,38 & 4,24 & 3,13 \\
\hline
\end{tabular}

Emlékezzünk vissza arra, hogy a szövegszavak száma szerint a mondategészek átlagos hosszúságában nem volt nagy különbség a három szövegcsoport között. A különbség a mondategészek tagoltságában mutatkozik meg. A magyar nyelvben az egy mondatra jutó információmennyiséget több mondategységben helyezzük el, mint az orosz nyelvben, és ezzel természetesen együtt jár, hogy az egy mondategységre jutó mondatszint alatti bővítmények száma is kevesebb lesz. A mondategységek bővítettségi mutatója a magyar szövegcsoportban $(3,13)$, ez kevesebb mint a fele az orosz mondategységek bővítettségi mutatójának $(6,38)$. A fordítások adataiból látszik, hogy a fordítók igyekeztek növelni a mondategységek számát, és csökkenteni a mondatszint alatti bővítettséget $(4,24)$, úgy is mondhatnánk, a mondat mélységét (Yngve 1973), de nem érték el az autentikus magyar szövegek szintjét.

A vizsgált 1342 mondategység képletének leírása és a számszerủ adatok manuális összesítése alapján megállapítható, hogy a magyar fordítások bizonyos szintaktikai mutatók tekintetében az orosz átlag és a magyar átlag között helyezkednek el. A monda- 
tegészek kevésbé tagoltak (1. skála), a mondategységek hosszabbak (2. skála), jobban bővítettek (3. skála), és egy mondatszintü elemre több mondatszint alatti bővítmény jut (4. skála), mint az autentikus magyar szövegekben.

\section{1. skála}

A mondategészek tagoltsága a forditásokban (mondategység/mondategész)

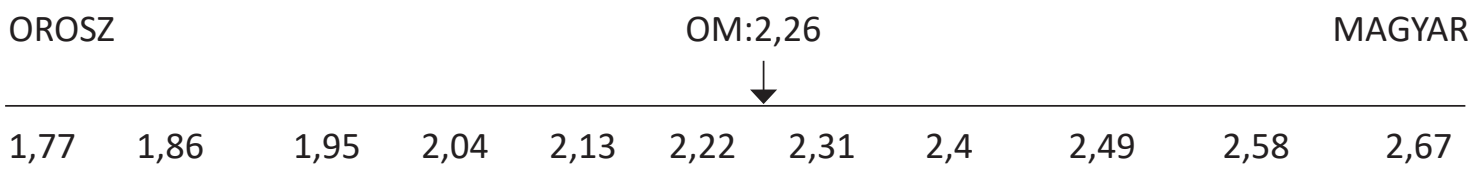

2. skála

A mondategységek hossza a forditásban (szövegszó/mondategység)

OROSZ

$\mathrm{OM}: 8,28$

MAGYAR

$\begin{array}{lllllllllll}10,5 & 10,18 & 9,87 & 9,56 & 9,25 & 8,94 & 8,63 & 8,32 & 8,1 & 7,7 & 7,39\end{array}$

3. skála

A mondategységek mondatszint alatti bövitettsége

(mondatszint alatti elem/mondategység)

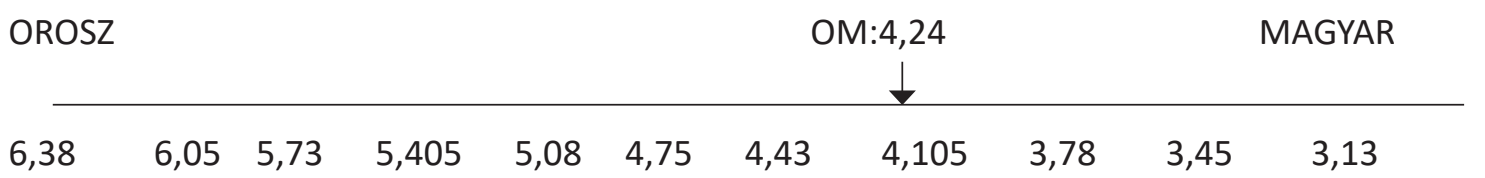




\section{4. skála}

A mondatszintü elemek mondatszint alatti bővitettsége

(mondatszint alatti elem/mondatszintü elem)

OROSZ

$\mathrm{OM}: 1,04$

MAGYAR

$\begin{array}{lllllllllll}1,54 & 1,45 & 1,37 & 1,29 & 1,21 & 1,13 & 1,05 & 0,97 & 0,89 & 0,81 & 0,73\end{array}$

Számításaink alátámasztják azt a tényt, amit fordítók, lektorok és szerkesztők intuitíve nyilván mindig is érzékeltek, hogy az oroszból fordított magyar szövegekben a mondategészek kevésbé tagoltak, azaz kevesebb mondategységből állnak, a mondategységek több mondatszint alatti bővítményt tartalmaznak, és hosszabbak bennük az alapszó előtt álló mondaszint alatti bővítményláncok. Ezek az eltérések csak szövegszinten érzékelhetők, hiszen a mondatok egyenként jól formált magyar mondatoknak tekinthetők.

\section{Kvázi-helyesség az OM mondatok aktuális tagolásában}

Szintén gyakorló fordításoktatói és lektorálási tapasztalataim mutatták, hogy a fordított szövegek jellegzetességeinek leírásában a téma-réma (a továbbiakban TR) viszonyokat is érdemes vizsgálni, hiszen a hallgatói fordításokban és a kiadói lektorálási megbízásaimban nagyon sokszor kellett szórendet javítanom. Az oroszból fordított magyar szövegekben későn világosodott meg a mondat szerkezete, eltolódtak a hangsúlyok, egyszóval fárasztó volt olvasni, megérteni őket. Mivel a magyar mondatok szórendje viszonylag szabad, a szófajok és mondatrészek nem pozícionálisan, hanem morfológiailag vannak meghatározva, ezeket a szórendi javításokat valóban csak szövegszinten lehetett indokolni. Ilyen indoklásokat adtam a javításaimban, hogy „Rövidítsük meg a mondat elejét, így szorosabbra füzzük a kapcsolatát az előző mondattal...”, „Hozzuk előre a támpontot, mert ha az igei állítmány a mondat végére csúszik, későn világosodik meg a mondat szerkezete..." stb. Bár tudományos szakszövegeket javítottam, ezeknek a tudományos szakszö- 
vegeknek is volt dallamuk, és gyakran éreztem, hogy a hangsúlyok a fordításban nem jó helyen vannak. Papp Ferenc azt írta, hogy a kvázi-helyes szövegek mondatai topic-comment szempontból is rendben vannak (lásd a cikk elején említett meghatározásának b) pontját), ebben én nem voltam olyan biztos.

A TR viszonyok feltárásához a három szövegcsoportot megpróbáltam kommunikatív egységekre (KE) bontani, azaz mindegyik mondategységében elkülönítettem a tematikus szakaszt a rematikus szakasztól, és a rematikus szakaszon belül elkülönítettem a rematikus csúcsot, a rematikus szakasz leghangsúlyosabb részét. Ezt úgy végeztem, hogy a mondategységek már meglévő szintaktikai képletében szögletes zárójellel jelöltem ki a kommunikatív tagolást, azaz a tematikus és rematikus szakaszt, és gömbölyü zárójellel a rematikus csúcsot. Azért használtam saját terminusokat, mert az általam használt terminusok nem egészen estek egybe a szakirodalomban akkor már széles körben használt topik, komment és fókusz terminussal (É. Kiss 1978).

A képlet leírását az M szövegcsoport egyik mondatával szemléltetem, elöször a mondatot mutatom be kommunikatív egységekre (KE) bontva, majd annak képletét. Az alsó indexekben a mondatszint alatt álló jelzői bővítményeket tömörítettem. A mondategész egyetlen mondategységből áll, a mondategységet bevezető tárgyi bővítmény a mondat tematikus szakasza, utána kezdődik a rematikus szakasz, ezen belül a határozó a rematikus csúcs, és az állítmány a rematikus szakasz leszálló ágában van, mint ezt majd a rématípusoknál látni fogjuk.

(2) ${ }_{\mathrm{T}}$ [A 48-as olasz szabadságharc bukásának végső okát $] \#_{\mathrm{R}}\left[\left(_{\mathrm{RCS}}\right.\right.$ a polgárság viszonylagos fejletlenségében) kell keresnünk.]

Képlete: ${ }_{\mathrm{T}}\left[{ }_{5} \mathrm{~T}\right] \#_{\mathrm{R}}\left[\left({ }_{\mathrm{RCS}}{ }_{2} \mathrm{H}\right){ }_{1}{ }_{1} \mathrm{~A} l 1\right] .(\mathrm{M}$ 8.1.)

A szakmai és tudományos szövegekben a mondatok nagy része természetesen objektív szórendü, az ismerttől (téma) halad az ismeretlen (réma) felé, tehát a mondategészek nagy része téma-réma (TR) tagolású. Ha meseszövegeket vizsgáltunk volna, ott 
találtunk volna sok szubjektív szórendü, azaz a rémától a téma felé haladó mondatot (pl. Ment mendegélt a farkas...). Kommunikatív egységekre lebontva a korpusz kis számban tartalmazott réma-téma (RT) tagolású mondategységeket, valamint csak rémát tartalmazó mondategységeket (komplex réma $=\mathrm{KR}$ ) és csak témát tartalmazó mondategységeket (komplex téma $=\mathrm{KT}$ ). A kommunikatív egységek száma minimálisan tért csak el a mondategységek számától: 600 mondat 1342 mondategységet és 1332 kommunikatív egységet tartalmazott, ezért a dolgozat további részeiben is a mondategység terminussal dolgoztam.

\section{6. táblázat}

A négy fö aktuális tagolási típus abszolút és százalékos megoszlása a három szövegcsoportban

\begin{tabular}{|l|c|c|c|c|c|c|}
\hline & \multicolumn{2}{|c|}{ O } & \multicolumn{2}{c|}{ OM } & \multicolumn{2}{c|}{ M } \\
\hline & KE száma & \% & KE száma & \% & KE száma & \% \\
\hline TR & 270 & 77,42 & 320 & 70,17 & 368 & 71,04 \\
\hline RT & 8 & 3,14 & 11 & 2,41 & 20 & 3,86 \\
\hline KR & 63 & 15,42 & 115 & 25,21 & 122 & 23,55 \\
\hline KT & 14 & 4,00 & 10 & 2,19 & 8 & 1,84 \\
\hline Összesen & 358 & 100,00 & 456 & 100,00 & 518 & 100,00 \\
\hline
\end{tabular}

Amint a 6. táblázatból látható, a három szövegcsoport nem különbözik jelentősen egymástól a fö aktuális tagolási típusok számszerü megoszlása tekintetében. A mondategységek határai megegyeznek a kommunikatív egységek határaival, és nagy részük objektív szórendű, azaz téma-réma tagolású. A további vizsgálat megmutatta, hogy az eltérések a tematikus és a rematikus szakaszok jellegzetes típusainak megoszlásában keresendők.

\subsection{Kvázi-helyesség a fordított szövegek tematikus szakaszában}

Röviden ki kell térnünk itt a szintaktikai mondattagolás és az aktuális (más terminussal értelmi vagy kommunikatív) mondattagolás viszonyára is, hiszen köztudott, hogy a két tagolás nem esik egybe: az alany nem mindig esik egybe a témával, az állítmány nem mindig esik egybe a rémával. Nyelvenként és müfajonként eltérö, hogy mi töltheti be a 
mondat témájának szerepét, mi állhat témaként. Az angolban például a szegényes morfológiai jellegzetesség miatt a mondat témája legtöbbször megegyezik a mondat alanyával, hiszen az alany pozícionálisan van meghatározva a mondat elején. A magyarban viszont gyakran állnak hely és időhatározók a mondat elején, és még az igei állítmánnyal való mondatkezdés sincs kizárva. Ilyen szempontból az orosz is gazdag morfológiájú nyelv, és bármi állhatna a mondat elején, számításaink viszont azt mutatták, hogy mégis az alanyi téma a leggyakoribb.

\section{7. táblázat}

A tematikus alanyok gyakorisága, hosszúsága és mondatszint alatti bövitettsége az $O$ és az M szövegcsoportban

\begin{tabular}{|l|c|c|}
\hline Az összevetésben szereplö mutatók & $\mathbf{O}$ & $\mathbf{M}$ \\
\hline alanyi TSZ/összes TSZ & $69,3 \%$ & $52,2 \%$ \\
\hline alanyi TSZ szószáma/alanyok száma & 3,81 szó & 2,53 szó \\
\hline alanyi TSZ mondatszint alatti bővítettsége / alanyok száma & 2,25 szó & 1,41 szó \\
\hline
\end{tabular}

Sokéves kontrollszerkesztési, fordatásoktatási gyakorlatom alapján feltételeztem, hogy a fordított szövegekben a kvázi-helyeség egyik megnyilvánulása a tematikus alanyok nagyobb gyakorisága, hosszúsága és bővítettsége lesz. Ilyen kezdetủ mondatokra gondoltam az OM szövegcsoportból:

(3) A szerzők általánosításai és javaslatai a művészi-tervezői megformálásra és a különféle termékfajták legjobb felhasználásra vonatkozólag... (OM 19.10)

(4) Mindezek a különböző időkbe tartozó és a folyamat szerves részét alkotó elemek... (OM 1.5.)

A számszerủ adatok ezt a feltételezésemet nem igazolták. A 6. táblázatban látható különbségek az orosz és a magyar szövegcsoport alanyi témáinak gyakorisági, hosszúsági és bővítettségi mutatói között nem tükröződtek a magyar fordításban, ahol a következő 
mutatókat kaptam: az OM szövegcsoportban a tematikus alanyok gyakorisága: 53,7\%, hosszúság 2,66 szó, mondatszint alatti bővítettség 1,36 szó. Ezek a mutatók alig térnek el az autentikus magyar szövegek mutatóitól (ld. 7. táblázat). Nem azt mondom, hogy az orosz tematikus szakaszok szintaktikai megformálásnak nincs hatása a fordított magyar szövegekre, de ez a hatás másképp jelentkezik: olyan mondatkezdéstípusok jelennek meg a fordított magyar szövegekben, amelyek az autentikus magyar szövegekben szokatlanok, ritkán vagy sohasem fordulnak elő.

Ezeknek a mondatkezdéstípusoknak a feltárásához háromféle tématípust különítettem el:

- Összefoglaló-visszautaló téma: az előző mondategység, mondategész vagy bekezdés tartalmát foglalja össze, vagy arra utal vissza.

- Informatív téma: új információt közöl, de ez az információ a szerző szándéka szerint csak bevezetés valami még fontosabbhoz, ami a mondat rematikus szakaszában található. Az informatív mondatkezdés azért téma, mert rajta kívül a mondatban van még fontosabb információt tartalmazó réma is.

- Retorikus téma: Olyan, rendszerint halmozott és bővített névszói szerkezettel megformált tematikus szakasz, amely tartalmát tekintve lehet akár visszautaló, akár informatív, az előző két típustól eltérően azonban olyan rematikus szakasz követi, amely nem hordoz fontosabb információt, csak leszögezi a tematikus szakaszban mondottak fontosságát (pl. mikor a szónoki beszédben az előadó a célok hosszas felsorolását úgy fejezi be, hogy ...ez a mi feladatunk).

\subsubsection{Az összefoglaló-visszautaló téma}

Az összefoglaló-visszautaló témában (a továbbiakban visszautaló téma) a visszautalás lehet explicit (pl. mutatónévmással), és lehet implicit, amikor a szerző a tematikus szakaszban mintegy összefoglalva megismétli az előző mondatban vagy mondatokban közölt információkat. Az orosz szerzők gyakran használják a szövegkoherencia megteremtésé- 
nek azt a módszerét, hogy névszói szerkezetté alakítva építik be az előző mondat vagy mondatok rematikus szakaszát a következő mondat tematikus szakaszába. Ez a lehetöség a magyarban is megvan, de az autentikus magyar szövegek szerzői a magyar főnevek korlátozottabb (szinte csak balra irányuló) bővítési lehetőségei miatt ritkábban élnek vele. Ezt mutatják korpuszom számszerü adatai is. Magyar szövegcsoportom első mondategységeinek visszautaló tematikus szakaszát vizsgálva a visszautalás módja az esetek 70,95\%-ban explicit volt, és csak 29,5\%-ban implicit. Az orosz szövegcsoport 56,25\%ban találtam explicit és 43,75\%-ban implicit visszautalást. Az impliciten visszautaló tematikus szakaszok tehát az orosz szövegcsoportban gyakoribbak voltak, mint a magyar szövegcsoportban.

A fordító ilyenkor két dolgot tehet. Ha meghagyja a szintaktikai formát, és a magyar főnevek bővítési lehetőségeit a végsőkig kihasználva főnévi szerkezettel fordít, akkor az olvasó számára túlságosan hosszú tematikus szakasszal kezdődő és első olvasásra nehezen érthető mondatot kap (5. példa). A másik lehetőség a szintemelő fordítás (6. példa). A mondat szintje alatt álló elemek a célnyelvben a mondat szintjére kerülnek, és ezzel új lehetőséget teremt a fordító a bővítmények elhelyezésére. De ezzel megváltoztatja a mondat kommunikatív szerkezetét is. Ennek elkerülésére szokták a fordítók „visszatematizálni” a felemelt szerkezeteket, és megjelennek, az $A z$, hogy ..., Az a tény, hogy... kezdetü mondatok. Léteznek a magyarban is, de a fordított szövegekben nagyobb gyakorisággal fordulnak elö.

(5) Szintemelés nélküli fordítás: A közvetlenül a vállalati számláról finanszírozott nagyjavítások ellenőrzésének a felügyeleti szervek által történő elmulasztása...

(6) Fordítás szintemeléssel: Az a tény, hogy a felügyeleti szervek nem ellenőrzik, mire költi a vállalat azt az összeget, melyet az elszámolási számláról a nagyjavításokra közvetlenül felvett... 
Ebben az esetben 500 mondatos mintákat vettem 3 OM és 3 M szövegböl, és az OM szövegeinkben 2-5-7 Az, hogy ... kezdetủ mondatot találtam, míg a három autentikus magyar mintában egyet sem. A szintemelő fordítás elé kitett „tematikus előjel” tipikus példája a forrásnyelvi szöveg közvetett interferenciájának.

\subsubsection{Az informatív téma}

Az informatív téma olyan mondatkezdö tematikus szakasz, amely nem visszautaló funkciót tölt be, hanem új információt hordoz. Informatív súlya ellenére sem tekinthető rémának, mert a szerző ugyanabban a mondatban valami még fontosabbat is akar közölni.

Orosz szövegcsoportunk TR tagolású mondatainak 27,3\%-a kezdődött informatív témával, átlagos hosszúságuk 6,58 szó, mondatszint alatti bővítettségük 2,39 szó volt. Magyar szövegcsoportunkban az informatív témával kezdődő mondatok aránya hasonló volt (23,3\%), de átlagos hosszúságuk csak 3,5 szó, mondatszint alatti bővítettségük pedig csak 0,94 szó. Más a szintaktikai megformálás is. Az informatív téma a magyar mondatok elején inkább idő vagy helyhatározó (45,7\%), és csak kisebb arányban alany 31,4\%, míg az oroszban az informatív téma $52,2 \%$-ban alanyi.

A hely- és időhatározós mondatkezdések az informatív téma természetes fajtái mindkét nyelvben, fordításuk semmilyen problémát nem okoz. Az orosz tudományos szövegekben azonban gyakran előfordul, hogy a szerzők a mondatkezdő alanyt is új információval terhelik meg, és ez a fordítókat nehéz helyzetbe hozza, különösen akkor, ha halmozott és bővített tematikus alanyokat kell lefordítania. Ezt szemlélteti a (7) példában az alábbi informatív tematikus alany:

(7) a valóságnak az ember által különböző módszerekkel és különböző absztrakciós szinteken megismert különféle oldalai között fennálló elvi jellegü feltételezettség és összefüggés... (OM 1.3) 
E mögött a nominális szerkezet mögött minimálisan két önálló mondategység rejlik. Az ember (A) megismeri (Áll) a valóságot (T) különbözö módszerek segítségével (H), és különbözö absztrakciós szinteken $(\mathrm{H}), s$ az így megismert valóság különbözö oldalai (A) összefüggnek (Áll), és kölcsönösen (H) feltételezik (Áll) egymást (T). Az informatív tematikus alanyok esetén a szintemelö fordítás nemcsak kényszermegoldás, mint a visszautaló téma esetében volt, hanem egyenesen kívánatos. Csak így tudja kiemelni a fordító a szerző által közölni akart új információt a névszói szerkezetek rabságából. És így van remény rá, hogy az olvasó is megérti, miről van szó. Hiszen, amint szintaktikai mutatóink számai is jelezték, az autentikus magyar szövegek szerzői az egy mondatra jutó információmennyiség növelését nem a névszói szerkezetek mondatszint alatti bővítettségének fokozásával, hanem az önálló predikátummal rendelkezö, önálló mondategységek számának növelésével oldják meg.

Természetesen a szintemelö fordításnak ebben az esetben is vannak veszélyei, hiszen sokszor a megértett gondolat nem maradhat így kibontva, mégiscsak a mondat témájáról van szó, tehát valahogy vissza kell csomagolni. Ha meghagyjuk az önálló mondategységeket, úgy növeljük a kötőszók és utalószók számát is. Mivel pedig gyakran fordulnak elő pótlólagosan betoldott kötőszós és utalószós megoldások a rematikus szakasz fordításakor, a kötőszók és utalószók számának növekedése szintén a fordított szövegek egyik csak szövegszinten nyomon követhető sajátosságává válik. A hogy kötőszós mondategységek számának növekedését a fordításban később nagyobb korpuszon és angol-magyar irányban is kimutattam (Klaudy 2009, 2017). Ezt az akkor kiszámolt eredményünket később nagy fordítási korpuszban is kimutatta Olohan és Baker (2000), amikor megállapították, hogy a that kötőszó nagyobb számban fordul elő az angolra fordított szövegekben, mint az autentikus angol szövegekben. A (8) példában az utalószók halmozását szemléltetjük egy OM szövegcsoportból vett példán.

(8) Az a helyzet, amely a világon az utóbbi három év során kialakult, teljesen nyilvánvalóan igazolja azt a tényt, hogy... (OM 3.3) 


\subsubsection{A retorikus téma}

Retorikus témának az olyan mondatkezdő tematikus szakaszokat nevezzük, amelyek lehetnek akár visszautalók, akár informatívak, a mondatban általában alanyi funkciójú, hoszszú és bővített esetleg halmozott névszói szerkezettel vannak kifejezve, és utánuk olyan rematikus szakasz következik, amely nem hordoz fontosabb információt, mint a tematikus szakasz, csak összefoglalja a témában mondottakat, leszögezi fontosságukat. Ilyen mondatokat a magyar szónoki nyelvben is találunk, de szakszövegekben ritkán. Ez az a pátosz, amely az akkori orosz nyelvü szakmai és tudományos szövegeket jellemezte. Az autentikus magyar szövegcsoport ilyen szerkesztésű mondatot nem tartalmazott, utoljára Kossuth Lajos beszédeiben találkoztam hasonlókkal. A fordító lehetőségeit szemléltessük az orosz nyelvủ szövegcsoport (O 4.2.) egy mondatának három fordítási változatával: (9a) megtartja az orosz retorikus témát, (9b) RT tagolású mondattal fordít, (9c) RT tagolású mondattal és szintemeléssel fordít. Ez utóbbi érthető a legjobban:

(9a) Nagy teljesítőképeségü, pontosan müködő nemzetközi szállítmányozási rendszer létrehozása, a szállítások összehangolására szolgáló korszerü módszerek bevezetése, valamint új együttmüködési területek kijelölése - ilyen feladatokat tüzött a program a szállítmányozási vállalatok elé.

(9b) A program a következő feladatokat tüzi szállítmányozási vállalatok elé: nagy teljesítőképeségü, pontosan müködő nemzetközi szállítmányozási rendszer létrehozása, a szállítások összehangolására szolgáló korszerű módszerek bevezetése, valamint új együttmüködési területek kijelölése.

(9c) A program a következő feladatokat tüzi szállítmányozási vállalatok elé: hozzanak létre nagy teljesítőképeségü, pontosan müködő nemzetközi szállítmányozási rendszert, vezessenek be korszerü módszereket a szállítások összehangolására, valamint jelöljenek ki új együttmüködési területeket. 


\subsection{Kvázi-helyesség a fordított szövegek rematikus szakaszában}

Amint említettük, a fő aktuális tagolási típusok (TR, RT, KR, KT) megoszlásában nincs lényeges számszerü különbség a három vizsgált szövegcsoport között: a szakmai és a tudományos szövegekre jellemző módon, a mondategységek többsége objektív szórendü, azaz az információ adagolása a témától halad a réma felé. A különbséget a tematikus és rematikus szakaszok típusainak megoszlása jelenti.

A rematikus szakaszok szintaktikai megformálását alapvetően befolyásolja az a tény, hogy az orosz mondatokra dominánsan az SVO (szubjektum-verbum-objektum), a magyar mondatokra dominánsan az SOV (szubjektum-objektum-verbum) szórend jellemző. Ennek megfelelően az orosz mondatokban a névszói tematikus szakasz (alany és/ vagy határozó és/vagy tárgy) után szinte mindig egy igei állítmány jelöli a téma és a réma közötti szakaszhatárt. A magyar mondatokban viszont gyakran előfordul, hogy a tematikus szakasz után nem ige következik, hanem az igei állítmány hangsúlyos bővítménye, a rematikus csúcs, amely szintén névszói megformálású. Így alakulhat ki, hogy az OM mondatok elején hosszan sorakoznak a névszói szerkezetek, és csak nagyon későn jutunk el a mondat szerkezetét világossá tevő állítmányig.

A rematikus szakasz szintaktikai megformálása alapján az orosz mondatokban négyféle rématípust különítettünk el: R1 = állítmány, $\mathrm{R} 2$ = alany és /vagy tárgy és/vagy határozó, R3 = gyenge igei állítmány + alany és /vagy tárgy és/vagy határozó, R4 = erős igei állítmány + alany és /vagy tárgy és/vagy határozó. Az oroszban nincs elváló igekötő, tehát az igei állítmány súlya szemantikai alapon dől el.

Ha a fenti rématípusokat a magyar szövegcsoportban próbáljuk megtalálni, látjuk, hogy az R1, R2 és R4 a magyarban is megvan, az R3 viszont nem létezik. A gyenge igei állítmány a magyarban nem állhat a rematikus szakasz elején, hiszen akkor az elötte álló bővítményt regresszíve rematikus csúccsá tenné. Fel kellett vennem egy ötödik rématípust (R5), amelyben a rematikus szakasz élén hangsúlyos bővítmény áll, ez a rematikus csúcs. A 8. táblázat mutatja a rématípusok megoszlását az orosz és a magyar szövegcsoport mondategységeiben. Felvettünk még egy hatodik típust is azokra a ritka esetekre (R6), amelyekben a rematikus szakaszon belül két rémacsúcs található. 
8. táblázat

A rematikus szakaszok fö típusainak számszerü megoszlása az $O$ és az M szövegcsoportban

\begin{tabular}{|l|c|c|c|c|}
\hline \multirow{2}{*}{ RSZ típusa } & \multicolumn{2}{|c|}{ O } & \multicolumn{2}{|c|}{ M } \\
\cline { 2 - 5 } & $\begin{array}{c}\text { abszolút } \\
\text { szám }\end{array}$ & \% & $\begin{array}{c}\text { abszolút } \\
\text { szám }\end{array}$ & \% \\
\hline R1. & 35 & 10,41 & 25 & 5,10 \\
\hline R2. & 62 & 18,45 & 37 & 7,55 \\
\hline R3. & 122 & 36,30 & --- & --- \\
\hline R4. & 113 & 33,63 & 178 & 36,32 \\
\hline R5. & --- & --- & 235 & 47,95 \\
\hline R6. & 4 & 1,19 & 15 & 3,06 \\
\hline Összesen & 336 & 100,00 & 490 & 100,00 \\
\hline
\end{tabular}

A 8. táblázatból látható, hogy az R3 és az R5 a két legnépesebb csoport, vagyis éppen abból a rématípusból van a legtöbb az orosz tudományos nyelvben, amelyik nem létezik a magyarban, és fordítva. Tehát akármelyik irányban fordítunk, a rematikus szakaszok nagy részének meg kell változtatni a típusát, és ez az egyszerủ szórendi átváltási műveletnek tünő $\mathrm{VO} \rightarrow \mathrm{OV}$ váltás nem végezhető el mechanikusan, mivel az orosz gyenge ige után rendszerint nem egy, hanem több bővítmény áll, és a fordítónak el kell döntenie, mit hoz be a magyar ige elé a rematikus csúcsra.

\subsubsection{Emelkedő (R3) és ereszkedő réma (R5)}

Ebben a rövid visszatekintésben nincs mód az összes rématípus fordításával kapcsolatos megfigyelések részletes leírására, csak a fenti két legfontosabbra. Ehhez szükségünk van Firbas (1964) „kommunikatív dinamizmus” fogalmának használatára, és négy saját fogalom bevezetésére, amelyeket annak idején a dolgozatban részletesen kifejtettem: a progresszív és regresszív rémajelölés, valamint az ereszkedő és emelkedő réma fogalmára (Klaudy 1987). 
Az orosz R3-at azért nevezzük emelkedő rémának, mert élén gyenge szemantikai töltésü ige áll, és a kommunikatív dinamizmus a mondat vége felé egyre nő. A magyar R5-öt azért nevezzük ereszkedő rémának, mert a gyenge vagy fordított szórendü igei állítmány a tőle balra álló bővítményekre helyezi a hangsúlyt, és az utána következő bővítmények kevesebb hangsúlyt kapnak.

Az orosz emelkedő rémában a rematikus csúcs jelölése progresszív (előre mutató), mert már a rematikus szakasz elején tudjuk, hogy a gyenge szemantikai töltésü igei állítmány után egyre hangsúlyosabb bővítmények következhetnek. A magyar ereszkedő rémában a réma jelölése regresszív (hátra mutató), mert a fordított szórendü vagy gyenge szemantikai töltésű igék utólag jelölik ki a tőlük balra álló rematikus csúcsot, és ha a fordító minden bővítményt behoz az ige elé, akkor csak a mondat végén világosodik meg a mondat szerkezete. Ezt mutatja az alábbi mondat az OM szövegcsoportból:

(10) [TSZ \# A gazdasági fejlődés jelenlegi szakaszában tökéletesítésük szükségességét] \# [RSZ (RCS a társadalmi termelés méreteinek növekedése, a népgazdasági kapcsolatok növekvő bonyolultsága és fokozódó intenzifikálása, a tudományos-technikai haladás ütemének meggyorsulása, az áru- és pénzviszonyok további fejlődése, és a tervezés módszereinek és a központi szervek szerepének megváltozása) határozza meg].

A (10) példában látható, hogy a fordított szórendű igei állítmány előtt (határozza meg) 28 szó áll a rematikus csúcson. De a tematikus szakasz utolsó szava után (szükségességét) semmi nem jelezte, hogy itt most a rematikus szakasz következik, ezt csak a mondat végén tudjuk meg. Azt, hogy a fordításokban az állítmány gyakran a mondat végére csúszik, a lektorok nyilván gyakran észreveszik és javítják. Nem tudatosan, de megpróbálják progresszívvé tenni a regresszív rémajelölést. Mondhatnák azt, hogy ne hozzunk be mindent az ige elé a rematikus csúcsra, használjuk ki a fordított szórendü igei állítmány utáni semleges zónát. Itt is megtehette volna a fordító, hogy a fordított szórendủ igei állítmányt előreviszi, és a felsorolás első tagja után helyezi el (a társadalmi termelés 
méreteinek növekedése határozza meg), a többi bővítményt pedig kiviszi az ige utáni semleges zónába, például a valamint beszúrásával.

Mindezt számszerủen is ki tudtuk mutatni. A 9. táblázatból látható, hogy a rematikus csúcs hossza és jelölésének módja eltér az autentikus magyar és a fordított magyar szövegekben.

\section{9. táblázat}

A rematikus csúcs (RCS) hossza és jelölésének módja az M és az OM szövegcsoportban

\begin{tabular}{|l|c|c|}
\hline Az összevetés egységei & M & OM \\
\hline RCS átlagos hossza & 3,2 szó & $3,8 \mathrm{szó}$ \\
\hline progresszíven jelölt RCS aránya & $47,21 \%$ & $30,55 \%$ \\
\hline regresszíven jelölt RCS aránya & $52,78 \%$ & $69,44 \%$ \\
\hline progresszíven jelölt RCS átlagos hossza & 3,03 szó & $3,32 \mathrm{szó}$ \\
\hline regresszíven jelölt RCS átlagos hossza & $3,13 \mathrm{szó}$ & $4,10 \mathrm{szó}$ \\
\hline
\end{tabular}

A 9. táblázatból látható, hogy az OM szövegekben hosszabbak a rematikus csúcsok, és több a csak regresszíven jelölt rematikus csúcs, mint az M szövegcsoportban. Mivel a magyar R5-re jellemző regresszív rémajelölés megértési nehézséget okozhat, az autentikus magyar szövegekben a regresszíven jelölt rematikus csúcsok nem szoktak túl hosszúak lenni, ritka bennük a halmozás, és a sok mondatszint alatti bővítmény elhelyezése. Ha a rematikus csúcson több halmozott és/vagy bővített névszói szerkezet van, az bizonytalanná teszi a TR szakaszhatárt. Ezt mutatja a (12) példa:

(12) [ [ TSZ \# Az ily módon kialakuló negatív emocionális alap, a pesszimizmus ] \# $\left[_{\mathrm{RSZ}}\left({ }_{\mathrm{RCS}}\right.\right.$ elmaradott egészségtelen nézetek, szokások, gondolatok) jó talajává válhat]. (OM 11.5)

Ha nem lennének zárójelek, nem tudnánk, hogy a pesszimizmus után vége a tematikus szakasznak, és a rematikus csúcs következik, inkább felsorolásnak, illetve halmo- 
zásnak gondolnánk, hiszen a grammatikai homonímia miatt az alany csak utólag válik el a hasonló szintaktikai formájú birtokos jelzőtől.

A regresszív rémajelölés progresszívvé tételét úgy is meg lehet oldani, hogy a rematikus csúcsnak csak a képviselőjét hozza be a fordító a gyenge igei állítmány elé. Ezt a müveletet a kezdő fordítók nem végzik el, a rutinosabbak elvégzik. Ezt illusztrálja a (12) példa két változata:

(12a) A tudásnak ez a két ága egymással szorosan összefüggő céljait a tudomány tényeinek minőségi elemzése alapján éri el. (hallgatói fordítás)

(12b) A tudásnak ez a két ága úgy közelíti meg egymással szorosan összefüggő céljait, hogy minőségileg elemzi a tudomány tényeit. (OM 1.11)

Mint a (12a) példából látható, a kezdő fordító minden bővítményt a gyenge igei állítmány (éri el) előtti rematikus csúcson helyezett el, míg a képzett fordító mondatában (12b) a rematikus csúcson csak a határozó bővítmény képviselője, az úgy utalószó található, a tárgyi bővítményt a fordított szórendủ igei állítmány utáni semleges zónában találjuk, a határozói bővítményt pedig a külön mondategységben helyezi el a fordító.

\subsubsection{A többi rématípus}

Az R1-ben a rematikus szakaszban egyetlen mondatszintü elem van: az igei vagy névszói állítmány. Mindkét nyelvre jellemző rématípus. Fordítása csak akkor okoz problémát, ha az orosz névszói állítmány szemantikailag gyenge, és utána sok posztpozitív bővítmény sorakozik. Ha a fordító az orosz mondat összes jobbra álló bővítményét behozza a magyar fönév elé, megint elmosódik a TR szakaszhatár, ahogyan a (13a) példa mutatja. 
(13a) Az enyhülés megvalósítása az államok közötti kapcsolatok kölcsönösen egyeztetett és szerződésben rögzített elveinek gyakorlati tartalommal való megtöltésére hivatott nemzetközi intézkedések széles körét felölelö fogalom. (hallgatói fordítás)

(13b) Az enyhülés megvalósítása nemzetközi intézkedések széles körét felölelő fogalom, ezek az intézkedések arra vannak hivatva, hogy... (OM 3.3)

A (13a) mondat grammatikailag helyes magyar mondat, de csak névszói szerkezetekből áll, és nehéz megérteni. A megjelent fordítás (13b) rutinosabb fordítója, elörehozta a támpontot, azaz a névszói állítmányt egyetlen bővítménnyel, és a többi bővítményt önálló mondategységben helyezte el. Itt tulajdonképpen új mondatot is kezdhetett volna, de nyilván nem akarta megváltoztatni a mondathatárokat.

Az R2-ben a rematikus szakaszban szintén csak egyetlen mondatszintü elem van, de nem az állítmány, hanem valamelyik másik mondatszintủ bővítmény, az alany, a tárgy vagy a határozó. Amikor a grammatikai tagolás és az aktuális tagolás különbségeiröl beszélünk, mindig hangsúlyozzuk, hogy a téma nem mindig az alany, a réma nem mindig az állítmány, ezért érdemes egyáltalán aktuális tagolásról beszélni. A 10. és 11. táblázat mutatja a rematikus alanyok arányát és mondatszint alatti bővítettségét a három szövegcsoportban.

A 10. táblázatból leolvasható, hogy az alanyra valóban elsősorban a témaszerep a jellemző, hiszen az alanyok nagy része mindhárom szövegcsoportban a tematikus szakaszban található. A 11. táblázat azt mutatja, hogy a rematikus alanyok bővítettsége mindhárom szövegcsoportban nagyobb, mint a tematikus alanyoké. Az is látszik, hogy az orosz szövegcsoportban található a legtöbb rematikus alany.

Ezek az adatok alátámasztják tapasztalati úton nyert feltételezésemet, hogy az orosz szakmai és tudományos nyelvben valóban létező tendencia az alanyok rematikus helyzetbe való juttatása és a lényeges mondanivaló rematikus alany formájában való kifejezése, ami a főnevesülési tendencia jele. 
Ezekben az oroszból fordított magyar mondatokban nincs ige, amely segítené a mondat szerkezetének megértését.

\section{0. táblázat}

Az alanyok megoszlás a téma és a réma között

\begin{tabular}{|l|c|c|c|}
\hline Alanyi megformálás & O & OM & M \\
\hline A tematikus szakaszban & $68,07 \%$ & $70,1 \%$ & $74,75 \%$ \\
\hline A rematikus szakaszban & $31,93 \%$ & $29,9 \%$ & $25,25 \%$ \\
\hline
\end{tabular}

\section{1. táblázat}

Az alanyok átlagos mondatszint alatti bövitettsége a témában és a rémában

\begin{tabular}{|l|c|c|c|}
\hline $\begin{array}{l}\text { Az alanyok átlagos mondatszint alatti bőví- } \\
\text { tettsége }\end{array}$ & $\mathbf{O}$ & $\mathbf{O M}$ & $\mathbf{M}$ \\
\hline A tematikus szakaszban & 2,15 szó & 1,25 szó & 1,18 szó \\
\hline A rematikus szakaszban & 4,58 szó & 2,88 szó & 1,83 szó \\
\hline
\end{tabular}

Az orosz eredetiben ilyenkor gyakran találunk является típusú üres igéket, de ezek a magyar fordításban nem jelennek meg.

(14) A fütőanyag- és energiaprobléma megoldásának a célprogramokban megjelölt fő útjai: a szilárd fütőanyagok termelésének növelése, a kőolaj-feldolgozás bővítése, az atomenergia-ipar fejlesztése, és az energiaigényes iparágaknak a fütóanyag-termelő területeken való elhelyezése. (OM 5.10)

A (14) példamondathoz hasonló halmozott és bővített alanyi rémák számszerủen is kimutatható gyakorisága igazolja azt az érzésemet, hogy az oroszból fordított magyar szövegek nominálisabbak, mint az eredeti magyar szövegek. 
Egyenletes rémáról (R4) akkor beszélünk, ha a rematikus szakasz elején erős igei állítmány áll, amely az egész rematikus szakasznak egyenletes kommunikatív töltést ad.

Ezt a magyarban az egyenes szórendủ igei állítmány vagy erős szemantikai töltésű ige teszi lehetővé. Mivel az oroszban nincs elváló igekötő, ott csak az ige szemantikai töltése játszik szerepet. Az erős igei állítmány balra tematikus szakaszt jelöl, jobbra egyenletes rémát. Ez a rématípus mindkét nyelvben előfordul, fordítása nem jelent nehézséget.

\section{Záró gondolatok}

Az elmúlt 40 évben nemcsak a korpusznyelvészet fejlődött, hanem jelentős társadalmi és politikai átalakulások is történtek. Ezeknek az orosz szövegeknek nagy részét ma már nem fordítanák le magyarra, míg a magyar szövegcsoportom szerzőit (pl. Hankiss Elemér, Huszár Tibor, Kulcsár Kálmán, Pataki Ferenc, Hanák Péter stb., vö. Klaudy 1987) ma is olvassák. Ezért is kell vigyázni a korpusznyelvészeti munkákban a szövegválasztással. A vizsgált korpusz orosz és oroszból fordított magyar szövegein nagyon érezni lehet a kort, amelyben születtek. Ez nem érvényteleníti a dolgozat alaptéziseit, hogy a professzionális fordítók által készített szövegek jellegzetességeit szövegszinten érdemes vizsgálni, hogy a fordított szövegeket autentikus célnyelvi szövegekkel érdemes egybevetni, és hogy disztribúciós különbségekről van szó, amelyeket számszerüleg is ki lehet mutatni.

Lett-e mindennek valami folytatása? A manuális elemzésnek és számolásnak nagy előnye a szövegközeliség. A szövegek aprólékos vizsgálata közben sok mindenre felfigyel az ember, amit az automatikus elemzés nem észlel. Például valaminek a hiányára. Ilyen volt a TR szakaszhatár jelölésnek hiánya a fordított szövegekben, illetve ennek a kommunikatív szakaszhatárnak az elmosódása, amit később európai uniós szövegek anyagán, angol end-focus jellegü (R3) mondategységek magyarra való fordításában is kimutattam (Klaudy 2004). Az orosz-magyar fordításokon végzett megfigyeléseimet beépítettem az indoeurópai nyelvekről magyarra és magyarról indoeurópai nyelvekre való fordítás átváltási műveleteinek tipologizálásába $(1994,2003)$. Építettem később kisebb automatikusan lekérdezhető angolból fordított magyar és autentikus magyar korpuszt is a fordításokat 
leleplező magyar nyelvi elemek kimutatására (2018). Két kutatót említek, aki folytatta a fordított szövegek aktuális tagolásának ilyen szellemü vizsgálatát: Aradi András (2019) és Pásztor Kicsi Mária (2012). A Fordítástudományi Doktori Program hallgatói közül Nagy János (2016) vágott bele angolról magyarra fordított szépirodalmi szövegek aktuális tagolásának vizsgálatába nagyon érdekes eredményekkel. Az aktuális (értelmi vagy kommunikatív) tagolás kutatásának korpusznyelvészeti eszközökkel való összekapcsolása azonban még mindig várat magára.

Amikor a nyolcvanas évek elején befejeztem a dolgozatomat, a Budapesti Müszaki Egyetem Számítóközpontjának egy munkatársa a következő megjegyzést tette: kár, hogy nem vártam a disszertációm megírásával egy-két évet, mert nemsokára az általam vizsgált 60 könyvet teljes egészében gépre lehet majd vinni, és automatikusan elemezni. Ha nem is egy-két év alatt, de valóra vált az álom. Mint a korpusznyelvészet későbbi fejlődése és e kötet további tanulmányai is mutatják, most már több millió szavas korpuszok automatikus elemzése folyik, cáfolva vagy igazolva a korai, kis korpuszokon manuálisan végzett elemzések megállapításait.

\section{Irodalom}

Aradi A. 2019. A mondatok információs szerkezetének és szintaktikai formájának viszonya a fordításban. Forditástudomány 21. évf. 1. szám. 5-23.

Baker, M. 1993. Corpus Linguistics and Translation Studies. Implications and Applications. In: Baker, M., Francis, G. and Tognini-Bonelli, E. (eds) Text and Technology: In honour of John Sinclair. Amsterdam: Benjamins. 233-250.

Baker, M. 1995. Corpora in Translation Studies. An Overview and Suggestions for Future Research. Target Vol. 7. No. 2. 223-245.

Deme L. 1971. Mondatszerkezeti sajátosságok gyakorisági vizsgálata. Budapest: Akadémiai Kiadó. 
É. Kiss K. 1978. A magyar mondatok egy szintaktikai modellje. Nyelvtudományi Közlemények 80. évf. 2. szám. 261-265.

Firbas, J. 1964. On Definig the Theme in Functional Sentence Analysis. Travaux linguistiques de Prague Vol. 1. 267-280.

Klaudy K. 1987. Fordítás és aktuális tagolás. Nyelvtudományi értekezések 123. Budapest: Akadémiai Kiadó.

Klaudy K. 1994. A forditás elmélete és gyakorlata. Budapest: Scholastica.

Klaudy K. 2003. Languges in Translation. Budapest: Scholastica.

Klaudy K. 2004. A kommunikatív szakaszhatárok eltünése a magyarra fordított európai uniós szövegekben Magyar Nyelvőr 128. évf. 4. szám. 389-407.

Klaudy K. 2018. Eredeti magyar szöveg vs. fordított magyar szöveg. In: Bódi Z., Hegedüs, R., Szöllősy-Sebestyén A. (szerk.) Magyar szaknyelvek a Kárpát-medencében. Budapest: Tinta Könyvkiadó.

Nagy J. 2012. A kommunikatív dinamizmus (relativ) egyensúlya a forditásban. Doktori értekezés. Kézirat. Budapest: ELTE.

Olohan, M., Baker, M. 2000. Reporting that in Translated English. Evidence of subconscious processes of explicitation? Across Langugaes and Cultures Vol. 1. No. 2. 141-158.

Papp F. 1972. Okoncsatyelnaja redakcija tyeksztovih jegyinyic dlinnyee predlozsenyija. Slavica XII. 27-41.

Papp F. 2005. A mondatnál hosszabb szövegegységek végső szerkesztése, avagy az idegen nyelvü beszéd kvázi helyessége In: Klaudy K. (szerk.) Papp Ferenc olvasókönyv. Budapest: Tinta. Fordította: Répási Györgyné. 122-135. 
Pásztor Kicsi M. 2012. A mai vajdasági magyar napi sajtó és elektronikus média informatív szövegeinek szintaktikai, intonációs és kommunikatív jellemzői. Újvidék: Újvidéki Egyetem, Bölcsészettudományi Kar.

Yngve, V. 1973. A mélységhipotézis. In: Szépe Gy. (szerk.) A nyelvtudomány ma. Budapest: Gondolat. 443-458. 